\title{
Penerapan Teori Big Push dalam Pengembangan Ekonomi Lokal untuk Mengatasi Kemiskinan Jember ${ }^{1}$
}

\section{Application of Big Push Theory in Local Economic Development to Overcome Regional Poverty.}

\author{
Wafi Farhan a , Ilham Wahyu a, Yuliatri Meganingrum ${ }^{\text {2 }}$ \\ ${ }^{a}$ Program Studi S1 Perencanaan Wilayah dan Kota, Jurusan Teknik Sipil, Fakultas Teknik, Universitas \\ Jember, Jl. Kalimantan 37 Jember
}

\begin{abstract}
ABSTRAK
Kemisikinan suatu daerah merupakan masalah besar yang selalu menjadi momok tiap tahunya. Kemiskinan daerah terjadi kaerana ketidakmampuan untuk memenuhi kebutuhan yang mendasar seperti pendidikan, pakan dan kesehatan. Kemiskinan dapat disebabkan karena sulitnya akses terhadap pendidikan dan pekerjaan. Menurut Friedman pengertian kemiskinan adalah ketidaksamaan kesempatan untuk memformulasikan kekuasaan sosial berupa asset, sumber keuangan, organisasi sosial politik, jaringan sosial, barang atau jasa, pengetahuan dan keterampilan, serta informasi. Teoru Big Push merupakan suatu teori untuk mendorong percepatan perekonomian disuatu daerah. Hal tersebut lebih efisien apabila dapat dikolaborisakn dengan pengembangan ekonomi lokal. Dimana pengembangan ekonomi lokal di gunakan untuk memaksimalkan pemanfaatan sumber daya lokal yang melibatkan masyarakat lokal, dunia usaha, pemerintah dan organisasi masyarakat untuk mengembangkan ekonomi suatu wilayah. Diharapkan kedua teori tersebut dapat menjadi solusi untuk mengatasi kemiskinan di suatu daerah.
\end{abstract}

Kata kunci: Teori Big Push, PEL,Kemiskinan

\begin{abstract}
The poverty of an area is a big problem that always becomes a scourge every year. Regional poverty occurs because of the inability to meet basic needs such as education, food, and health. Poverty can be caused by difficult access to education and employment. According to Friedman, the notion of poverty is the inequality of opportunities to formulate social roles, financial assets, social-political organizations, social networks, goods or services, knowledge and skills, and information. The Big Push theory is a theory to encourage the acceleration of performance in an area. It is more efficient for developers to have collaborated with local economic development. Where local economic development is used to increase the utilization of local resources that require local communities, businesses, governments, and community organizations to develop the economy in a region. It is hoped that these two theories can be a solution to overcome poverty in an area
\end{abstract}

Keywords: Teori Big Push, PEL, Poverty

\footnotetext{
${ }^{1}$ Info Artikel: Received: 30 Desember 2019, Accepted: 14 Januari 2020

${ }^{2}$ E-mail: wafihermawan1987@gmail.com (Wafi Farhan), ilhamwahyuhartono18@ gmail.com (Ilham

Wahyu), Yuliatry43@gmail.com (P. Ketiga)
} 


\section{PENDAHULUAN}

Jember adalah salah satu kebupaten di Jawa timur. Kabupaten Jember berada di lereng pegunungan Argopuro yang mempentang ke arah selatan hingga samudra Indonesia, Kabupaten Jember mempunyai kedudukan dan peran stategis sebagai salah satu Pusat Kegiatan Wilayah (PKW). Keberadaan kabupaten Jember Secara geografis memiliki potensial baik dari sejarah maupun bentang alam. Dalam pengembanganya kabupaten Jember mengalami perkembangan perekonmian yang pesat yaitu timbulnya pusat-pusat perdagangan baru utama pedagangan hasi pertanian, seperti padi, palawija dan pergeseran distrik pemerintahan dari wuluhan ke Balung, puger ke kencong. Dalam pengembanganya yang dirilis oleh BPS Kabupaten Jember tercatat sebagai kabupaten dengan jumlah penduduk miskin paling banyak se Jawa Timur. Hal tersebut membuat kabupaten Jember mengalami penurunan pengeloaan perekonomian wilayah. Salah satu indikator keberhasilan pertumbuhan ekonomi suatu daerah yaitu angka kemiskinan dalam pembangungan suatu daerah. Maka dari itu permasalahan itu harus segera diatasi agar kemisikinan di Jember dapat berkurang.

Pengembangan suatu daerah dapat dikatakan berhasil dan gagal bisa dilihat berdasarkan perubahan pada tingkat kemiskinan (Suryahardi dan Sumarto). Kemiskinan adalah salah satu penghambat pembangunan suatu daerah yang ditandai dengan tingginya pengangguran, keterbelakangan, maupun keterpurukan. Minimnya fasilitas yang mudah diakses membuat masyarakat miskin sangat menghambat kegiatan sosial ekonomi. Dalam konteks demikian kemiskinan sangat erat dengan kapasitas dalam suatu daerah. kabupaten Jember dengan jumlah penduduk terbesar ke 3. Luas wilayah kabupaten Jember sendiri sebesar $3.292 \mathrm{~km} 2$ dan dengan jumlah penduduk sejumlah 2.332.726 jiwa dengan tingkat pertumbuhan penduduk sebesar $0,55 \%$. Selain itu, kabupaten Jember merupakan salah satu barometer perekonomian di jawa timur, hal ini terlihat dari besarnya jumlah Produk Domestik Regional Bruto (PDRB) kabupaten Jember yang menduduki peringkat ke 9 dari 33 kabupaten/kota yang ada di provinsi jawa timur setelah kota Surabaya, Kediri, sidoarjo, pasuruan, gresik, malang, madiun, dan mojokerto. Aktivitas ekonomi yang ada di kabupaten Jember sejalan dengan tingginya aktivitas masyarakat dalam berbagai sektor ekonomi yang ada di kabupaten Jember. Hal tersebut menjadi paradigma dengan progam pengentasan kemiskinan yang dapat bermuara pada keberhasilan atau pun kegagalan. Menurut data yang didapat dari BPS jumlah penduduk miskin pada tahun 2016 mencapai 265.100 KK. Jumlah ini meningkat pada tahun 2017 mencapai sebesar $266.900 \mathrm{KK}$. Jumlah ini meningkat sebesar $0.03 \%$ dari jumlah penduduk di Kabupaten Jember. Pemerintah Kabupaten Jember seringkali berupaya untuk mengetaskan kemisikinan seperti melakukan bantuan perlindungan sosial rumah tangga miskin hingga pemberdayaan usaha mikro dan kecil.

Dalam mengatasi dan menanggapi permasalahan tersebut dapat dimaksimalkan dengan pengembangan ekonomi lokal. Pengembangan ekonomi lokal mengacu pada proses proses dimana pemerintah lokal atau organisasi berbasis masyarakat berusaha menggerakan dan memelihara aktivitas bisnis dan kesempatan kerja. Tujuan utama PEL adalah untuk merangsang kesempatan kerja lokal pada sector tertentu untuk meningkatkan kesehjateraan masyarakat dengan menggunakan SDM dan SDA. PEL berorientasi pada yaitu pengembangan institusi baru , industri alternative, memperbaiki kapasitas kerja , 
identifikasi pasar baru, transfer pengetahuan, dan memelihara perusahaan dan usaha yang baru (Blakely, 1994). Untuk penselaraskan pola pengembangan perekonomian harus dikaitkan dengan sektoral suatu daerah. Menurut penelitian yang dilakukan Ivan Agusta (2013) mengungkapkan bahwa hasil analisis jalur telah didapatkan pola keterkaitan sektoral. Dengan mengetahui adanya hubungan tersebut maka mengindikasikan adanya pengaruh antara satu dengan lainnya. Besaran pengaruh sektor terhadap pertumbuhan ekonomi dapat dilihat berdasarkan besaran nilai dari hasil analisa regresi pada masing - masing sektor. Lalu perubahan kinerja sektoral (hasil produksi) memberikan pengaruh yang positif pada pertumbuhan ekonomi.

Untuk mengtaskan kemiskinan dan mengembangkan PEL dapat menerapkan teoru big push sebagai tolak ukut. Big Push atau "daya dorong yang besar" bisa juga diartikan sebagai modal dan infrastruktur. Kemudahan modal dan keberpihakannya kepada daerah berkembang merupakan langkah yang strategis. Setiap harinya derah perlu mengembangkan daerahnya sesuai kebutuhan dan permintaan seperti pengembangan infrastruktur yang menghubungkan banyak banyak daerah dengan pusat bisnis sepertinya memang perlu diprioritaskan oleh pemerintah. Upaya pemerintah dalam mengejar ketertinggalan ekonomi, pemerataan pendapat dan pertumbuhan ekonomi adalah dengan memprioritaskan pembangunan dan pengembangan infrastruktur di berbagai sektor dan juga melakukan investasi pada berbagai sektor.Berdasarkan hasil penelitian dari Riyandani (2010), menunjukkan bahwainvestasi swasta memiliki pengaruh positif dan signifikan terhadap pertumbuhan ekonomi. Lalu penelitian Amelia (2010) juga mengatakan hal yang sama jikainvestasi swasta memiliki pengaruh positif dan signifikan terhadap pertumbuhan ekonomi. Investasi juga berpengaruh terhadap penyerapan tenaga kerja pada industri kecil dan menengah, maka dari itu investasi di sektor industri kecil maupun industri menengah memiliki kecondongan pengaruh positif yang meningkat terhadap penyerapan tenaga kerja di suatu daerah. Penyerapan tenaga kerja tersebut dapat mengurangi penyebab terjadinya kemiskinan yaitu pengangguran. Semakin sedikit pengangguran maka pertumbuhan ekonomi akan meningkat. Lalu investasi dijalankan untuk pembangunan dan pengembangan infrastruktur yang ada. Berdasarkan penelitian Nugraheni (2018),Desa dengan kemiskinan tinggi akan menganggarkan alokasi belanja pembangunan yang lebih besar untuk memperbaiki infrastruktur desa. Artinya dengan pembangunan infrastruktur diharapkan mampu untuk mengurangi kemiskinan masyarakat. Penerapan Big Push dilakukan dengan mengkompresikan kebijakan agar regulasi dapat dipangkas agar tidak menghambat laju perekonomian.

\section{Sasaran dan Tujuan}

Sasaran penelitian ini adalah untuk merumuskan program terkait pengembangan perekonomian guna bersumbangsi terhadap upaya mengurangan jumah masyarakat miskin di Kabupaten Jember bedasarkan teori Big Push dan PEL. Maka dari itu penelitian ini bertujuan untuk memberi solusi untuk mengatasi kemisikinan di Jember dengan penerapan PEL dan Teori Big Push.

\section{KAJIAN PUSTAKA}

\section{Kemiskinan}

Kemisikinan dapat diartikan sebagai keadaan dimana terjadi ketidakmampuan untuk memenuhi kebutuhan dasar hidup seperti sandang, papangan maupun papan. Kemisikinan merupakan bumerang bagi pengembangan suatu daeran dan menjadi masalah global.. Sebagian orang memahami istilah ini secara subyektif dan komparatif, sementara yang lainnya melihatnya dari 
segi moral dan evaluatif, dan yang lainnya lagi memahaminya dari sudut ilmiah yang telah mapan. Kemiskinan dipahami dalam berbagai cara.

Kemisikinan dapat digambarkan dengan bentuk kekurangan materi, yang biasanya mencakup kebutuhan pangansehari-hari, sandang, perumahan, dan pelayanan kesehatan. Kemiskinan dalam arti ini dipahami sebagai situasi kelangkaan barang-barang dan pelayanan dasar. Gambaran lainya yaitu terkait dengan kebutuhan sosial seperti terkucilnya dalam masyarakat, ketergantungan, ketidakmampuan untuk berpartisipasi dalam masyarakat.

Definisi secara umum yang lazim dipakai dalam perhitungan dan kajian- kajian akademik adalah pengertian kemiskinan yang diperkenalkan oleh Bank Dunia yaitu sebagai ketidakmampuan mencapai standar hidup minimum (Word Bank, 1990). Friedman mendefinisikan kemiskinan (Usman, 2006) sebagai ketidaksamaan kesempatan untuk mengakumulasikan basis kekuatan sosial. Basis kekuatan sosial tidak terbatas hanya pada (1) modal produktif atau aset (misalnya organisasi sosial politik yang dapat digunakan untuk mencapai kepentingan bersama, partai politik, sindikasi, koperasi dan lain-lain), tetapi juga pada (2) net work atau jaringan sosial untuk memperoleh pekerjaan, barang- barang dan lainlain; (3) pengetahuan dan ketrampilan yang memadai; dan (4) informasi yang berguna untuk memajukan kehidupan mereka.

United Nations Development Program (UNDP) mendefinisikan kemiskinan sebagai ketidakmampuan untuk memperluas pilihan-pilihan dalam hidup). Jhingan (2000) mengemukakan tiga ciri utama negara berkembang yang menurutnya menjadi penyebab dan sekaligus akibat, yang saling terkait, dari kemiskinan yang terjadi. Ciri pertama, prasarana dan sarana pendidikan yang tidak memadai sehingga menyebabkan tingginya jumlah penduduk buta huruf dan tidak memiliki keterampilan atau keahlian. Ciri kedua, sarana kesehatan dan pola konsumsi buruk sehingga hanya sebagian kecil penduduk yang bisa menjadi tenaga kerja produktif.

Kemiskinan dapat menyebabkan laju pertumbuhan ekonomi menjadi terhambat. Kemiskinan dapat dibedakan dalam dua definisi yaitu kemiskinan absolut dan kemiskinan relatif. Kemiskinan secara absolut ditentukan berdasarkan ketidakmampuan untuk mencukupi kebutuhan pokok minimum seperti pangan, sandang, kesehatan, perumahan dan pendidikan yang diperlukan untuk hidup dan bekerja. Kebutuhan pokok minimum diterjemahkan sebagai ukuran finansial dalam bentuk uang. Nilai kebutuhan minimum kebutuhan dasar tersebut dikenal dengan istilah garis kemiskinan. Penduduk yang pendapatannya dibawah garis kemiskinan digolongkan sebagai penduduk miskin. Garis kemiskinan absolut (tidak berubah) dalam hal standar hidup, garis kemiskinan absolut mampu membandingkan kemiskinan secara umum. Sebagai contoh garis kemiskinan Amerika Serikat tidak berubah dari tahun ke tahun. 


\section{PEL}

Judul Pendekatan ekonomi lokal mengacu pada proses di mana pemerintah lokal atau organisasi berbasis masyarakat berusaha menggerakan dan memelihara aktivitas bisnis atau kesempatan kerja. Faktor dalam PEL dapat diklasifikasikan berdasarkan teori yang dikaji antara lain teori ekonomi nonklasik, teori kausasi kumulatif, dan model atraksi. Hal tersebut diterapkan dalam konsep baru.

Tabel 1 Komponen Lama dan Komponen Baru

\begin{tabular}{|l|l|l|}
\hline Komponen & Konsep Lama & Konsep Baru \\
\hline Kesempatan Kerja & $\begin{array}{l}\text { Lebih banyak perusahaan }= \\
\text { lebih banyak pekerjaan }\end{array}$ & $\begin{array}{l}\text { Perusahaan mengembangkan } \\
\text { kualitas pekerjaan sesuai dengan penduduk } \\
\text { lokal }\end{array}$ \\
\hline Basis Pembangunan & $\begin{array}{l}\text { Membangun sector sector } \\
\text { ekonomi }\end{array}$ & Membangun institusi ekonomi baru \\
\hline Aset Lokasi & $\begin{array}{l}\text { Keunggulan komperatif } \\
\text { berbasis asset fisik }\end{array}$ & $\begin{array}{l}\text { Keunggulan bersaing berbasis kualitas } \\
\text { lingkungan }\end{array}$ \\
\hline Sumber Daya & Ketersediaan tenaga kerja & $\begin{array}{l}\text { Pengetahuan dan ilmu sebagai } \\
\text { penggerak ekonomi }\end{array}$ \\
\hline
\end{tabular}

Sumber : Blakely (1994)

Dalam pengembanganya PEL termuat dalam alur kebijakan sebagai berikut :

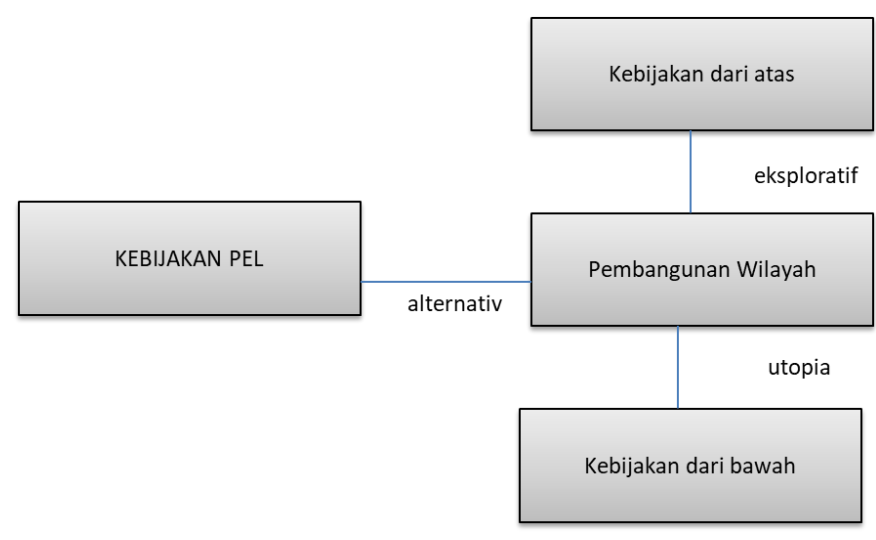

Gambar 2 Kebijakan pembangunan wilayah dengan pendekatan PEL

Peran pemerintah lokal dalam PEL adalah menciptakan kondisi yang baik bagi berkembangnya wirausahawan dan meningkatkan pembangunan lokal. Dengan tahahapan sebagai berikut :

- Pengorganisasian

- Evaluasi stategi sebelumnya

- Merangsang masuknya investasi

- Menyusun rencana strategi untuk pembangunan ekonomi lokal

- Menciptakan system PEL dan mengimplementasikan dalam rencana strategis

- Monitoring dan evaluasi

Kemudian dalam PEL terdapat unsur dasar yang dapat dijadikan indikator terdiri atas

- Mobilisasi dan partisipasi dari actor-aktor lokal

- Sikap proaktif pemerintah lokal

- Keberadaan tim kepemimpinan lokal 


\section{Jurnal Matrapolis}

- Kerja sama sector public dan swasta

- Persiapan strategi PEL

- Promosi usaha UMKM dan pelatihan SDM

- Koordinasi promosi progam dan instrument

- Pengembangan industri PEL

\section{Big Push Teori}

Secara umum, teori ini dicetuskan pertama kali oleh Paul Narcyz Rosenstein-Rodan. Big Push Model muncul karena di latarbelakangi dengan adanya rencana dan program investasi skala besar untuk mempercepat industrialisasi negara negara di Eropa Timur dan Tenggara. Pada negara berkembang, teori Big Push digunkan untuk memotong rantai kemiskinan yaitu dengan pola investasi dalam skala besar di sektor industri. Seiring berjalananya waktu teori ini kemudian dikembangan oleh Ragnar Nurkes, beliau menyatkan bahwa pembangunan harus dilakukan dengan mengembangkan semua sektor secara bersamaan, seimbang dan merata. Teori ini juga sering dikenal dengan konsep pembangunan strategi berimbang yang dapat diartikan sebagai laju berjalananya investasi secara bersamaan dan beragam yang digunkana untuk mendorong permintaan agregat, secara komplementer.

Teori Big Push atau "daya dorong yang besar" sangat erat modal dan infrastruktur. Kemudahan modal dan keberpihakannya kepada daerah berkembang merupakan langkah yang strategis. Pembangunan dan pengembangan infrastruktur yang menghubungkan banyak daerah dengan pusat bisnis sepertinya memang perlu diprioritaskan oleh pemerintah. Asumsi model pertumbuhan seimbang terdapat pelengkap praktis dan komersial dalam industri pada proses produksi di berbagai sektor sesuai dg external economics dan produksi besar-besaran serta serentak.Oleh karena itu model pertumbuhan seimbang ini sering di sebut sebagai Big Push Theory oleh segolongan ahli ekonomi.

- Pembayaran Faktor Produksi

- Permintaan Domestik

- Penawaran dan Permintaan Internasional

- Struktur Pasar

- Teknololgi

- Faktor Produksi

\section{METODE}

Pendekatan studi dalam proses perumusan penerapan teori big push dan pengembangan ekonomi lokal yang digunakan untuk mengatasi kemiskinan menggunakan pendekatan kualitatif. Pendekatan kualitatif menekankan konsep naratif dan deskripsi yang diarahkan pada fenomena terkait dengan kemiskinan di Jember. Kemudian dilkaukan penelitian kualitatif dengan mengidentifikasi indikator terkat dengan PEL, Teori Big Push, dan kemiskinan. Kemudian di komperkan dengan analisis SWOT untuk menghasilkan progam guna meuwujudkan progam untuk mengatasi kemiskinan dibawahnya. 


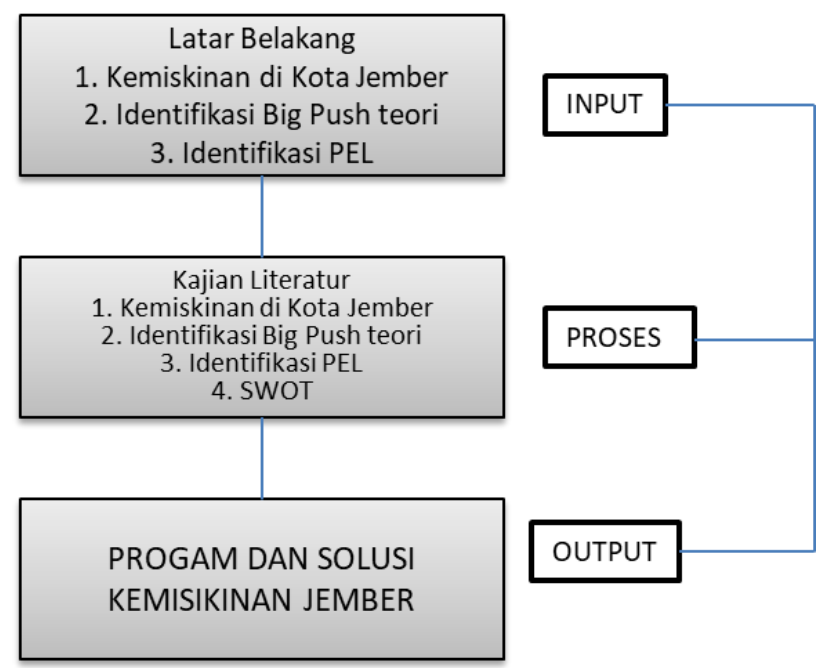

Gambar 2 Alur Pikir

\section{Kajian Literatur dan Data}

Kajian literature adalah teknik analisis secara kualitatif untuk menentukan indikator- indikator dari PEL dan teori Big Push yang selaras dengan penanganan kemiskinan. Kajian literatur diawali dengan identifikasi PEL, penyebab kemisikinan, dan teori bigpush. Data didapat dari hasil obesrvasi primer dan sekunder.

\section{Identifikasi Keterhubungan}

Identifikasi keterhubungan berkaitan dengan hasil identifikasi yang telah ditemukan pada kajian literature yang dihubungkan dengan masing-masing indikator lainya. Indikator tersebut meliputi kemiskinan di Jember, Big Push Teoti, dan PEL . Keseluruhan indikator tersebut dihubungkan melalui proses analisis kualitatif dan SWOT. Adapun identifikasi keterhubungan meliputi identifikasi nilai pada Big Push terhadap Kemiskinan Jember dan identifikasi nilai PEL terhadap kemiskinan Jember.

\section{SWOT}

Swot merupakan teori yang digunakan untuk meneliti kekuatan, kelemahan, peluang dan ancaman. Kekuatan dilihat untuk mengetahui progam yang akan dijalankan akan lebih maju dibandingkan pesaing yang ada. Begitu juga kelemahan dilihat agar dapat memperbaiki keadaan yang ada agar lebih baik. Peluang yang ada harus dimanfaatkan secara baik dan benar sesuai dengan porsinya agar dapat menekan volume peningkatan jumlah kemiskinan dan ancaman yang akan dihadapi oleh daerah haruslah dihadapi dengan mengembangkan strategi kebijakan yang baik. Menurut Rangkuti (2006) mengemukakan bahwa SWOT adalah singkatan dari lingkungan internal stregths dan weaknesses serta lingkungan eksternal Opportunities dan Threats yang dihadapi dunia bisnis. Analisis SWOT membandingkan antara faktor eksternal Peluang (Opportunities) dn Ancaman (Threats) dengan faktor internal kekuatan (Strengths) dengan kelemahan (Weaknesses). Sedangkan Koter (2002) mengemukakan bahwa analisis SWOT adalah evaluasi terhadap keseluruhan kekuatan, kelemahan, peluang dan ancaman disebut analisis SWOT. Berikut merupakan contoh tabel SWOT. 
Jurnal Matrapolis

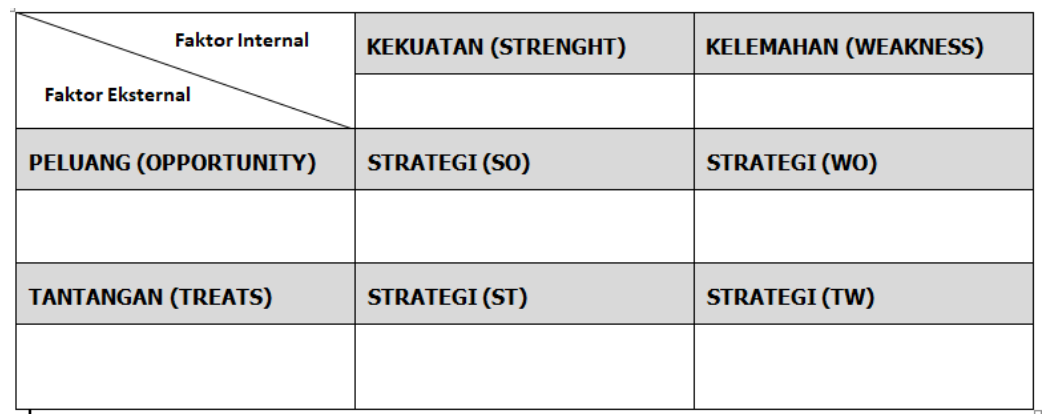

Gambar 3 Tabel SWOT

\section{HASIL DAN PEMBAHASAN}

\section{Gambaran Umum Kemiskinan Jember}

Kemiskinan disebabkan oleh dua aspek besar yang biasa disebut primer dan sekunder. Aspek primer dapat dijabarkan dengan komponen seperti miskin aset (harta), organisasi sosial politik, pengetahuan, dan keterampilan. Sementara itu aspek sekunder berupa miskin terhadap jaringan sosial, sumber-sumber keuangan dan informasi. Menurut Nugroho dan Dahuri (2012), kemiskinan merupakan suatu kondisi absolut atau relatif di suatu wilayah di mana seseorang atau kelompok masyarakat tidak mampu mencukupi kebutuhan dasarnya sesuai tata nilai atau norma yang berlaku. Apabila dilihat dari sudut pandang aspek ekonomi, kemiskinan menunjuk pada gap antara lemahnya keinginan dalam memenuhi kebutuhan dasar.
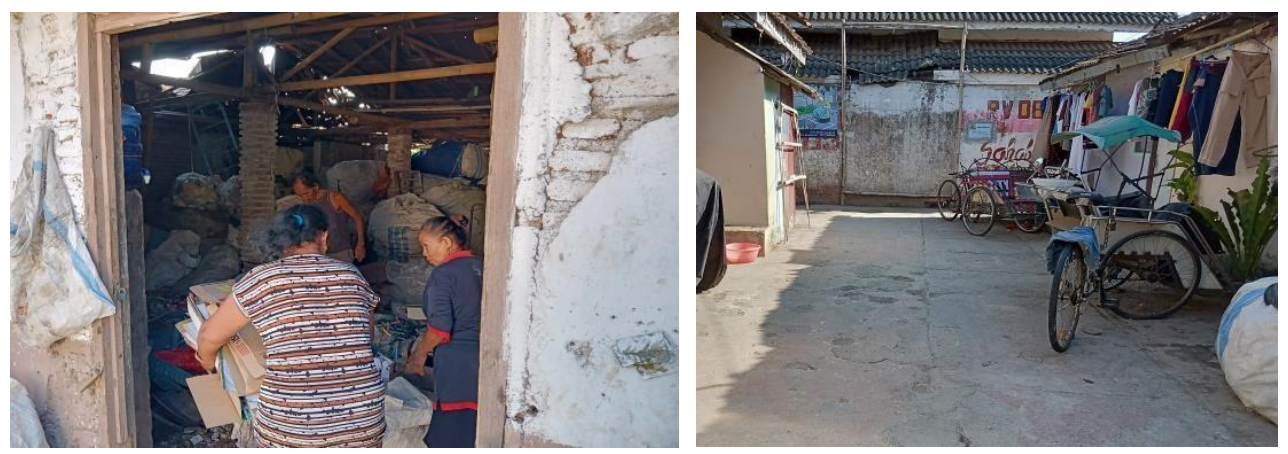

Gambar.3 Kondisi Perekonomian Masyarakat Keluarga Miskin Jember Sumber : Survei Primer, 2019

Menurut data dari BPS Kabupaten Jember menduduki peringkat ke 2 dengan orang miskin terbanyak kedua di Jawa Timur. Daerah yang memiliki kemisikinan tertinggi adalah diantaranya Kecamatan Tempurejo sebanyak 9.470 RTM, Kecamatan Silo sebanyak 14.105 RTM, Kecamatan Mumbulsari sebanyak 11.550 RTM, Kecamatan Sumberbaru 
sebanyak 13.516 RTM, Kecamatan Bangsalsari 13.197 RTM, Kecamatan Kalisat 12.247 RTM, Kecamatan Ledokombo 13.035 RTM, Kecamatan Sumberjambe 11.945 RTM dan sebanyak 11.309 RTM di Kecamatan Sukowono. Karakteristik keluarga miskin di Kabupaten Jember dapat diketahui dari tingkat perekonomian, pola hidup, dan jenis pekerjaan.

Secara kultural mayoritas penduduk kabupaten Jember terdiri dari suku Jawa dan Madura yang dikenal dengan istilah pendhalungan. Suku Madura merupakan suku terbanyak di kabupaten Jember. Suku Madura terlihat dominan di Kabupaten Jember bagian utara dan marupakan mayoritas di sejumlah tempat. Apabila dipandang dari aspek geografis, daerah yang menjadi kantong kemiskinan di Kabupaten Jember yaitu di wilayah utara tepatnya di kecamatan Kalisat yang mayoritas penduduknya berkultur Madura. Sedangkan di daerah Selatan jumlah penduduknya lebih sedikit dibandingkan dengan daerah Utara seperti kecamatan Ambulu yang mayoritas masyarakatnya berkultur Jawa.

\section{Penerapan PEL pada Kemisikinan Jember}

Pendekatan Ekonomi lokal sangat cocok diterapkan di Jember. Hal tersebut didukung dengan penerapan konsep baru dan hasil pengkajian. Penerapan ekonomi lokal secara khusus beraspek pada kebijakan perusahaan yang harus mengembangkan kualitas pekerjaan dengan penduduk lokal, mengembangan Perguruan Tinggi di Jember untuk membangun institusi ekonomi yang baru, menciptakan daya saing global dan lokal. Mayoritas masyarakat Jember bekerja sebagai petani, perekonomian Jember masih banyak digantungkan dari sektor pertanian. Di Jember sendiri terdapat banyak area perkebunan, sebagian besar peninggalan Belanda. Perkebunan yang ada dikelola oleh Perusahaan nasional PTP Nusantara, Tarutama Nusantara (TTN), dan Perusahaan daerah yaitu PDP (Perusahaan Daerah Perkebunan). Jember terkenal sebagai salah satu daerah penghasil tembakau utama di Indonesia.Tembakau Jember adalah tembakau yang digunakan sebagai lapisan luar/kulit cerutu. Di pasaran dunia tembakau Jember sangat dikenal di Jerman dan Belanda.Kemudian PEL juga membahas tentang jenjang tahapan dalam memastikan progam dan kebijakan yang akan dibuat.

- Kebijakan diatas

Kebijakan diatas yang ada di Jember dikaitkan dengan munculnya progam dan peraturan daerah Kabupen Jember untuk mengatasi masalah kemiskinan. Jember yang memiliki wilayah yang cukup luas membuat pemerintah kewelahan untuk mengimplementasikan progam dan output perdanya karena sosialisai dan penyebaran tidak merata.

- Pembangunan wilayah

Pembangunan wilayah adalah upaya mencapai pembangunan berimbang (balance development). Isu pembangunan wilayah atau daerah berimbang yaitu tidak mengharuskan adanya kesamaan tingkat pembangunan antar daerah (equally developed), juga tidak menuntut pencapaian tingkat industrialisasi wilayah atau daerah yang seragam, juga bentuk-bentuk keseragaman pola dan struktur ekonomi daerah, atau juga tingkat pemenuhan kebutuhan dasar (self sufficiency) setiap wilayah atau daerah. Pembangunan yang berimbang adalah terpenuhinya potensipotensi pembangunan sesuai dengan kapasitas pembangunan setiap wilayah atau daerah yang beragam (Murry, 2000).

- Kebijakan dari bawah

Kebijakan dari bawah diartikan sebagai dorongan yang dilakukan oleh masyarakat atau tokoh yang berpengaruh untuk memberi sebuah suntikan ide dan modal agar masyarakat sekitar dapat berkembang dan keluar dari permasalahan kemiskinan. Peran pemerintah lokal dalam PEL adalah menciptakan kondisi yang baik bagi berkembangnya wirausahawan dan meningkatkan pembangunan lokal. Kemudian dalam PEL terdapat unsur dasar yang dapat dijadikan indikator terdiri atas 


\section{Jurnal Matrapolis}

- Mobilisasi dan partisipasi dari actor-aktor lokal.

Mobilisasi dikaitkan dengan aktivitas aksesbilitas dari pusat bisnis ke daerah pemasok. Hal tersebut dapat di jelaskan melalui lokasi dan permainan penjualan barang dan jasa. Di Jember sendiri mobilitas dadn partisipasi actor-aktor lokal diketahui dari jarak pusat pertanian dan pasar sehingga hal tersebut dapat berpengaruh pada jumlah dan harga jual bagi petani lokal.

- Sikap proaktif pemerintah lokal

Sikap pro aktif pada pemerintah lokal yaitu terkait dengan mengawal segara peraturan agar dapat seimbangan dan tidak berat sebelah. Proaktif juga dilakuakan dengan melaporkan hasil implementasi progam yang telah dijalankan sudah sesuai apa belumnya. Menurut pengamatan dari masalah yang terjadi di Kota Jember masyarakat masih mengekor terhadap kebijakan yang dibuat. Saat terjun di lapangan banyak masyarakt yang mengeluh terhadap bantuan pemerintah yang tidak sesuai.

- Keberadaan tim kepemimpinan lokal

Keberadaan tim kepemimpinan lokal adalah structural kepemimpinan yang berada pada skala masyarakat kecil, menengah, dan atas. Ritme pola kepempinan yang ada di kabupaten Jember masih banyak di pegang oleh steakholder dengan basic agama dan pesantren.

- Kerja sama sector public dan swasta

Kerja sama sector public dan swasta harus sudah banyak terjadi di kabupaten Jember. Khususnya pada bidang perkebunan dan pertanian. Kerja sama tersebut berupa penyerapan tenaga kerja. Penjualan produk lokal dan sejenisnya.

- Persiapan strategi PEL

Persiapan stratrgi PEL dengan melakuakn pengumpulan data potensi lokal baik alam maupun buatan untuk dimanfaatkan dengan mengacu pada strategi PEL yang telah dirancang

- Promosi usaha UMKM dan pelatihan SDM

Promosi UMKM dilakukan dengan mengkordinir setiap wilayah dan jenis UMKM dengan disertai peningkatan keahlian berupa pelatihan SDM.

- Koordinasi promosi progam dan instrument

Jember masih belum memiliki branding yang bagus sehingga banyak budaya dan potensi Jember yang belum dimanfaatkan secara maksimal.

- Pengembangan industri PEL

Pengemban industri PEL dilakukan dengan mengadopsi bahan dari kabupaten Jember dan dijual secara menyeluruh agar pemenuhan hasil industri dapa dipenuhi.

\section{Penerapan Big Push}

Asumsi model pertumbuhan seimbang terdapat pelengkap praktis dan komersial dalam industri pada proses produksi di berbagai sektor sesuai dg external economics dan produksi besarbesaran serta serentak. Oleh karena itu model pertumbuhan seimbang ini sering di sebut sebagai Big Push Theory oleh segolongan ahli ekonomi.

- Faktor Produksi

Kota Jember terkenal sebagai penghasil kakao terbesar di Jawa Timur. Maka dari itu menurut data BPS Jember rata produksi kakao mencapai 600.000 ton per tahun. Perkebunan di Kabupaten Jember terdiri dari 11 komoditas perkebunan yang terdiri dari tebu, kelapa, tembakau Na-Oogst, tembakau Vor-Oogst, kopi, pinang, kapuk, cengkeh, panili, jambu mete dan lada. Produksi komoditas perkebunan kopi menempati urutan kelima dengan tingkat produksi dalam bentuk ose kering sebesar 1976,87 ton, setelah produksi komoditas kelapa, komoditas tembakau (Na-Oogst dan Vor-Oogst), dan komoditas tebu.

- Tekhnologi

Kota Jember sendiri sudah terkenal sebagai penghasil tembakau akan tetapi di Kabupaten pengolahanya masih menggunakan system tradisional

- Permintaan Domestik

Permintaan domestik merupakan kebutuhan yang harus dipenuhi oleh suatu daerah begitu juga di pada kabupaten Jember, Di Kabupaten Jember sendiri terdapat Tujuh kecamatan di Kabupaten Jember yang memiliki produksi kopi yang tinggi daerah tersebut adalah Kecamatan Ledokombo,

24 | Penerapan teori big push 
Vol.1, No.1, 2020, p.15-30

Kecamatan Sumberjambe, Kecamatan Jelbuk, Kecamatan Silo, Kecamatan Panti, Kecamatan Tanggul dan Kecamatan Sumberbaru. Daerah tersebut dapat disebut sebagai daerah sentra produksi kopi di Kabupaten Jember. Tingginya produksi kopi di daerah tersebut belum tentu menunjukkan bahwa daerah tersebut merupakan daerah basis untuk komoditi kopi. Oleh karena itu perlu adanya kajian tentang sektor basis untuk sektor tersebut

- Penawaran dan Permintaan Internasional

Permintaan Internasional adalah peluang berupa kerjasama ekspor terhadapa komoditi unggulan .. salah satunya adalah kakao. Angka ekspor kakao Indonesia menunjukkan adanya kenaikan pada beberapa komoditi, dimana nilai ekspor yang paling besar disumbang oleh komoditi cocoa beans, whole or broken, raw or roasted yang besarnya sekitar $74 \%$. Kenaikan ekspor kakao mentah berbanding terbalik dengan produk olahan yang relatif mengalami penurunan ekspor mengindikasikan bahwa pengusaha kakao lebih memilih mengekspor kakao dalam bentuk biji daripada mengolah kakao di dalam negeri. Gejala semacam ini tidak baik dan belum diterapkan di Jember

- Struktur Pasar

Struktur pasar merupakan penggolongan pasar berdasarkan strukturnya. Jember senditi termasuk dalam persaingan pasar sempurna. Jenis pasar dengan jumlah penjual dan pembeli yang banyak dan produk yang dijual bersifat homogen. Persaingan akan terjadi apabila penjual dan pembeli dalam jumlah besar mengadakan saling hubungan secara aktif dengan maksud memaksimumkan keuntungan dan kepuasan atas dasar harga-harga yang ditentukan oleh penawaran dan permintaan. Contoh produknya seperti beras,gandum, dan kentang. Pasar persaingan sempurna memiliki ciri-ciri

- Jumlah penjual dan pembeli banyak

- Barang yang dijual bersifat homogen

- Penjual bersifat mengambil harga (price taker)

- Posisi tawar komsumen kuat

- Sulit memperoleh keuntungan di atas rata-rata

- Sensitif terhadap perubahan harga

- Mudah untuk masuk dan keluar dari pasar

\section{HASIL SWOT}

\section{SWOT PEL}

Analisis SWOT adalah penilaian terhadap hasil identifikasi situasi, untuk menentukan apakah suatu kondisi dikategorikan sebagai kekuatan, kelemahan, peluang atau ancaman.

1) Kekuatan (Strength)

Kekuatan merupakan kondisi internal pada daerah Jember berupa kompetensi maupun sumberdaya yang dimiliki Jember yang dapat digunakan sebagai alternatif untuk menangani dan ancaman. PEL mempunyai kekuatan yang sudah teridentifikasi, yaitu:

- Jember memilii potensi yang besar dalam bidang pertanian

- Jember memiliki banyak perguruan tinggi

- Pemerintah banyak melakukan pelatihan

2) Kelemahan (Weakness)

Kelemahan merupakan kondisi internal di daerah Jember dimana kompetensi dan sumberdaya Jember sulut untuk dikembangkan untuk menangani kesempatan dan ancaman yang ada. Berikut identifikasi kelemahan yang ada:

- Jember belum memiliki branding yang bagus dan budaya yang mencirikan Jember

- Masyarakat masih belum proaktif terhadap pemerintah lokal

3) Peluang (Opportunity)

Peluang dapat diartikan sebagai situasi luar ataupun eksternal Jember yang berpotensi mengutungkan. Jember yang berada dalam satu industri yang saama secara umum akan merasa diuntungkan bila dihadapkan pada kondisi eksternal tersebut.

- Jember memiliki sda dan sdm yang melimpah

- Jember mempunyai banyak sector public yang bisa digunakan untuk system kerja sama 
4) Ancaman

\section{Jurnal Matrapolis}

(Threat) adalah suatu keadaan eksternal yang berpotensi menimbulkan kesulitan. Daerah Jember yang berada dalam satu industri yang sama secara umum akan merasa dirugikan, dipersulit, bahkan terancam bila dihadapkan pada kondisi eksternal tersebut.

- Wilayah Jember yang luas

- Kurang merata

- Masih tradisional

\section{SWOT BIG PUSH}

Analisis SWOT adalah penilaian terhadap hasil identifikasi situasi, untuk menentukan apakah suatu kondisi dikategorikan sebagai kekuatan, kelemahan, peluang atau ancaman.

1) Kekuatan (Strength)

Kekuatan merupakan kondisi internal pada daerah Jember berupa kompetensi maupun sumberdaya yang dimiliki Jember yang dapat digunakan sebagai alternatif untuk menangani dan ancaman. Big Push Teori mempunyai kekuatan yang sudah teridentifikasi, yaitu, yaitu:

- Jember memiliki tingkat produksi kakao yang tinggi yaitu 600.000 ton perhari

- Permintaan domestic yang terus meningkat khususnya kopi

2) Kelemahan (Weakness)

Kelemahan merupakan kondisi internal di daerah Jember dimana kompetensi dan sumberdaya Jember sulut untuk dikembangkan untuk menangani kesempatan dan ancaman yang ada. Berikut identifikasi kelemahan yang:

- Jember belum memiliki branding yang bagus dan budaya yang mencirikan Jember

- Masyarakat masih belum proaktif terhadap pemerintah lokal

3) Peluang (Opportunity)

Peluang dapat diartikan sebagai situasi luar ataupun eksternal Jember yang berpotensi mengutungkan. Jember yang berada dalam satu industri yang saama secara umum akan merasa diuntungkan bila dihadapkan pada kondisi eksternal tersebut.

- Jemebr masih trradisional belum ada teknnoligi

- Ekspor yang belum maksimal.

4) Ancaman (Threat) adalah suatu keadaan eksternal yang berpotensi menimbulkan kesulitan. (Threat) adalah suatu keadaan eksternal yang berpotensi menimbulkan kesulitan. Daerah Jember yang berada dalam satu industri yang sama secara umum akan merasa dirugikan, dipersulit, bahkan terancam bila dihadapkan pada kondisi eksternal tersebut

- Wilayah Jember yang luas

- Kurang merata perkembangan perekonomian

- Masih tradisional

\section{Matriks SWOT PEL}

Setelah mengetahui strength (Kekuatan), weakness (ancaman), opportunity (peluang), threat (ancaman) yang ada pada Jember, Maka langkah selanjutnya adalah menyusun matriks SWOT. Matriks SWOT adalah alat yang penting untuk membantu manajer mengembangkan empat tipe strategi yaitu SO (strengths-opportunities), WO (weakness- opportunities), ST (strengthsthreats), dan WT (weaknesess-threats). 
1) Strategi $\mathrm{SO}$

SO merupakan strategi yang digunakan berdasarkan jalan pikiran organisasi yaitu untuk memanfaatkan seluruh kekuatan dengan memanfaatkan peluang sebesar besarnya. Hal ini merupakan strategi agresif yang bersifat positif dengan penuh inisiatif dan terencanan. Data program atau kegiatan yang akan dilaksanakan tepat sesuai kondisi yang ada sehingga tujuan organisasi akan tercapai secara terencana dan terukur. Dalam strategi SO, organisasi mengejar peluang-peluang dari luar dengan mempertimbangkan kekuatan organisasi. Strategi yang disusun berdasarkan analisis ini adalah:

- Jember harus bersinergai untuk memanfaatkan bidang pertanian yaitu dengan meningkatkan mutu sehingga dapat memberi manfaat bagi masyarakat yang luas.

- Keberadaan PTN dan PTS diharapkan memberi kontribusi berupa ide dan hasil penelitian untuk diterapkan dan disosiaslisakan kepada masyarakat luas

- Perusahaan pemerintah maupun swasta harus bersinergi dengan baik khususnya pada bidang pertanian untuk dimanfaat hasil produksinya sebagai pemenuhan kebutuhan masyarakat.

2) Strategi WO

WO merupakan strategi yang ditetapkan atas dasar pemanfaatan peluang dengan cara meminimalisir kelemahan dalam suatu organisasi. Dengan ini perlu dirancang sebuah strategi untuk merubah haluan . Peluang eksternal yang besar dan prioritas sangat penting untuk diraih. Namun analisi ini dala pengembanganya terdapat internal Jember lebih utama untuk dicarikan suatu solusi sehingga capaian peluang dapat diatasi. Dalam hal ini kelemahan-kelemahan Jember perlu diperbaiki dan dicari solusinya untuk memperoleh peluang tersebut. Identifikasi strategi dari hasil analisis ini adalah:

- Jember harus branding kota yang berkelanjutan agar dapat menarik pengunjung lokal maupun internasional dan juga investor

- Akademisi harus berperan aktif dalam mengawal kebijakan pemerintah yang harus mengacu pada pro rakyat kecil dan mengatasi kemiskinan

3) Strategi ST

ST merupakan strategi yang diambil berdasarkan kekuatan yang dimiliki Jember untuk mengatasi ancaman yang diprioritaskan. Strategi ini sering dikenal dengan istilah Strategi ini dikenal dengan strategi perbedaan. Maksud dari strategi tersebut adalah seberapa besar pun ancaman yang ada, kepanikan dan ketergesa-gesaan hanya memperburuk suasana, untuk itu bahwa Jember yg memiliki kekuatan yang besar yang bersifat independen dan dapat digunakan sebagai senjata untuk mengatasi ancaman tersebut diharapkan mampu mengidentifikasi kekuatan dan menggunankannya untuk mengurangi ancaman dari luar. Identifikasi strategi dari hasil analisis ini adalah:

- Wilayah Jember yang luas harus diatasi dengan memeratakan potensi di 31 kecamatan yang ada

- Kota Jember harus mengadakan pelatihan berupa pemenuhan teknologi agar pengolahan tradisional yang notabenya lambat dapat dipercepat baik kualitas maupun kuantitas

4) Strategi WT

WT merupakan konsep strategi yang ditetapkan dalam bentuk kegiatan yang bersifat defensif dan berusaha meminimalkan kelemahan yang ada serta menghindari ancaman. Karena dalam kondisi ini, Jember yang sedang dalam bahaya karena kelemahan menimpa kondisi internal dangan ancaman dari luar juga akan menyerang. Bila tidak mengambil strategi yang tepat, maka kondisi ini bisa berdampak buruk bagi citra dan eksistensi Jember ke depan. Hal yang perlu di cegah dengan bersama seluruh elemen Jember merencanakan suatu kegiatan untuk mengurangi kelemahan Jember, dan menghindar dari ancaman eksternal. Identifikasi strategi pada analisis ini adalah:

- Wilayah Jember yang luas dapat dieksplorisasi dalam pengembangan branding kota

- Masyarakat harus aktif kepada pemerintah agar tidak tertinggal teknologi 


\section{Matriks SWOT Big Push}

Setelah mengetahui strength (Kekuatan), weakness (ancaman), opportunity (peluang), threat (ancaman) yang ada pada Jember, Maka langkah selanjutnya adalah menyusun matriks SWOT. Matriks SWOT adalah alat yang penting untuk membantu manajer mengembangkan empat tipe strategi yaitu SO (strengths-opportunities), WO (weakness- opportunities), ST (strengthsthreats), dan WT (weaknesess-threats).

1) Strategi $\mathrm{SO}$

SO merupakan strategi yang digunakan berdasarkan jalan pikiran organisasi yaitu untuk memanfaatkan seluruh kekuatan dengan memanfaatkan peluang sebesar besarnya. Hal ini merupakan strategi agresif yang bersifat positif dengan penuh inisiatif dan terencanan. Data program atau kegiatan yang akan dilaksanakan tepat sesuai kondisi yang ada sehingga tujuan organisasi akan tercapai secara terencana dan terukur. Dalam strategi SO, organisasi mengejar peluang-peluang dari luar dengan mempertimbangkan kekuatan organisasi. Strategi yang disusun berdasarkan analisis ini adalah:

- Masyarakat Jember harus kecanduan kopi asli Jember agar produksi kopi dapat meningkat

- Jember memiliki produksi kakao terbesar yang harus di salurkan ke pasar pusat maupun linhkunagn

2) Strategi WO

WO merupakan strategi yang ditetapkan atas dasar pemanfaatan peluang dengan cara meminimalisir kelemahan dalam suatu organisasi. Dengan ini perlu dirancang sebuah strategi untuk merubah haluan . Peluang eksternal yang besar dan prioritas sangat penting untuk diraih. Namun analisi ini dala pengembanganya terdapat internal Jember lebih utama untuk dicarikan suatu solusi sehingga capaian peluang dapat diatasi. Dalam hal ini kelemahan-kelemahan Jember perlu diperbaiki dan dicari solusinya untuk memperoleh peluang tersebut. Identifikasi strategi dari hasil analisis ini adalah:

- Jember harus merambah pasar lokal khususnya di daerah tapal kuda

- Jember harus meningktkan kualitas kopi dan kakao agar dapat diekspor ke luar negeri

3) Strategi ST

ST adalah strategi yang ditetapkan berdasarkan kekuatan yang dimiliki Jember untuk mengatasi ancaman yang terdeteksi. Strategi ini dikenal dengan istilah strategi diversifikasi atau strategi perbedaan. Maksudnya, seberapa besar pun ancaman yang ada, kepanikan dan ketergesa-gesaan hanya memperburuk suasana, untuk itu bahwa Jember yg memiliki kekuatan yang besar yang bersifat independen dan dapat digunakan sebagai senjata untuk mengatasi ancaman tersebut diharapkan mampu mengidentifikasi kekuatan dan menggunankannya untuk mengurangi ancaman dari luar. Identifikasi strategi dari hasil analisis ini adalah:

- Perkebunan produksi kakao jangan terpusat di satu titik saja namun harus merata

- Produksi kakao harus menggunakan mesin canggih

4) Strategi WT

WT adalah strategi yang diterapkan ke dalam bentuk kegiatan yang bersifat defensif dan berusaha meminimalkan kelemahan yang ada serta menghindari ancaman. Karena dalam kondisi ini, Jember yang sedang dalam bahaya, kelemahan menimpa kondisi internal dangan ancaman dari luar juga akan menyerang. Bila tidak mengambil strategi yang tepat, maka kondisi ini bisa berdampak buruk bagi citra dan eksistensi Jember ke depan. Hal yang perlu di lakukan adalah bersama seluruh elemen Jember merencanakan suatu kegiatan untuk mengurangi kelemahan Jember, dan menghindar dari ancaman eksternal. Identifikasi strategi pada analisis ini adalah:

- Wilayah Jember yang luas harus dimanfaatkan untuk meningkatkan variasi pengeksploran

- Produksi perkebunan harus memanfaatkan teknologi yang canggih dan terupdate 


\section{KESIMPULAN}

Strategi penanggulangan kemiskinan di Jember menggunakan analisis SWOT dengan dipadukan melalui teori big push dan PEL maka pendekatan reformis adalah pendekatan yang tepat dalam menanggulangi masalah kemiskinan. Berdasarkan hasil analisis menunjukkan bahwa wilayah utara dan timur Kabupaten Jember merupakan daerah dengan jumlah penduduk miskin tertinggi yaitu Kecamatan Ledokombo, Kalisat dan Silo. Hasil analisis pendapat gabungan para informan atau key persons bahwa strategi yang paling penting dalam menanggulangi kemiskinan di Kabupaten Jember yaitu dengan berbasis pengembangan industri pertanian. Diikuti oleh kriteria berbasis program-program pendukung lain; kriteria pemberdayaan usaha ekonomi; dan kriteria berbasis bantuan dan perlindungan sosial. Dengan demikian, diharapkan bahwa penanggulangan kemiskinan di Kabupaten Jember lebih diprioritaskan dengan berbasis pemberdayaan masyarakat yang di dalamnya terdapat program Program Nasional Pemberdayaan Masyarakat (PNPM). Penanganan kemisikinan harus ditanggulangi dengan penyediaan lapangan pekerjaan yang banyak dan luas sehingga masyarakat misikin yang notabenya penganggurang dapat mendapatkan pekerjaan. Jember harus selalu bersinergi di bidang pertanian agar dapat menjadi lumbung pangan dan bermanfaat bagi seluruh masyarakat dari hulu ke hilir. Hal itu harus didukung oleh pengembangan Akademisi guna memberikan suntikan ide dan gagasan agar strategi lebih berkualitas. Adanya banyak perusahaan perkebunan harus mempriotitaskan masyarakat lokal sebagai pekerjanya dan mengambil bahan dari lahan masyarakat lokal dengan harga yang stabil. Jember juga harus memeiliki branding yang terstruktu agar dapat menarik pengunjung sehingga menghasilkan lapangan pekerjaan baru. Kota Jember harus mengadakan pelatihan berupa pemenuhan teknologi agar pengolahan tradisional yang notabenya lambat dapat dipercepat baik kualitas maupun kuantitas. Masyarakat Jember harus kecanduan kopi asli Jember agar produksi kopi dapat meningkat. Diharapkan rekomendasi tersebut dapat mengatasi kemiskinan di Jember dan mengurangi angka pengangguran.

\section{DAFTAR PUSTAKA}

Arsyad, Hendrik. 1999. "Penentuan Perencanaan dan Pembangunan Ekonomi Daerah". BPFE. Yogyakarta.

Farizkha, Ivan Agusta dan Santoso, Eko Budi. (2013). Keterkaitan Sektoral di Kabupaten Lumajang. Jurnal Teknik Pomits, II (2), C230-C233.

Hadiyanti, Sofia Ulfa Eka. (2015). Pengaruh Investasi Pada Industri Kecil dan Industri Menengah Terhadap Penyerapan Tenaga Kerja di Kota Samarinda. Malang: Universitas Brawijaya

Hermanto Siregar dan Dwi Wahyuniarti, 2008. Dampak Pertumbuhan Ekonomi Terhadap Penurunan Jumlah Penduduk Miskin. Jurnal Fakultas Ekonomi Universitas Diponegoro.

Jhingan, M.L. 1983. Ekonomi Pembangunan dan Perencanaan. Terjemahan oleh D. Guritno. 2012. Jakarta: Rajawali Press.

Khalid, Umer, dkk. 2005. Determinants of Poverty in Pakistan: A Multinomial Logit Approach. The Labore Journal of Economics, 10(1): 65-81.

Krisnawati, Estifania. Agus Suman. Putu Mahardika Saputra. (2018). Kajian Pengaruh Program Nasional Upaya Khusus Peningkatan Produksi Padi Terhadap Kemiskinan Perdesaan di Wilayah Barat dan Timur Indonesia. Malang: Universitas Brawijaya

Kuncoro, Mudrajad. 2003. Ekonomi Pembangunan: Teori, Masalah, dan Kebijakan. Yogyakarta: UPP AMP YKPN. 


\section{Jurnal Matrapolis}

Kuncoro, Mudrajad. 2003. Ekonomi Pembangunan: Teori, Masalah, dan Kebijakan. Yogyakarta: UPP AMP YKPN.

Mok, T.Y, dkk. 2007. The Determinants of Urban Poverty in Malaysia. Journal of Social Sciences, 3(4): 190-196

Purnomo Andri. 2013. Identifikasi Faktor Penyebab Kemiskinan Di Kabupaten Jember: Jurnal Fakultas Ekonomi Universitas Jember.

Remi, Sutyastie Soemitro dan Prijono Tjiptoherijanto. 2002. Kemiskinan dan Ketidakmerataan di Indonesia. Jakarta: Rineka Cipta.

Riyandani, Rifkiana Yulfa. (2010). Analisis Pengaruh Investasi Swasta, Investasi Pemerintah dan Ekspor Terhadap Pertumbuhan Ekonomi Provinsi di Indonesia Periode 2001-2006. Skripsi Tidak Dipublikasikan. Surabaya: Universitas Airlangga

Susila, Ihwan. 2007. Analisis Efesiensi Lembaga Keuangan Mikro. Jurnal Ekonomi Pembanguan vol. 8 No.2 Desdember 2007.

Wirosardjono, Soetjipto. 1992. Pengentasan Kemiskinan dan Statistik. dalam buku Tika Noorjaya. Strategi, Perencanaan dan Evaluasi Pengentasan Kemiskinan. Jakarta: CFMS. 